\title{
SCANNING ELECTRON MICROSCOPY OF HUMAN SPERMATOZOA AGGLUTINATED HEAD-TO-HEAD BY SPERM-AGGLUTINATING ANTIBODIES
}

\author{
J. FRIBERG AND O. NILSSON \\ Department of Obstetrics and Gynaecology, and \\ Institute of Human Anatomy, University of Uppsala, Uppsala, Sweden
}

(Received 31st December 1973)

\begin{abstract}
Summary. Human spermatozoa agglutinated head-to-head by spermagglutinating antibodies have been examined by means of scanning electron microscopy. Two types of union were observed, that between the anterior and middle parts of the sperm heads, and a second type where the anterior part of the head of the sperm cell attached to the postnuclear cap region of another spermatozoon. The possible significance of these findings is briefly discussed.
\end{abstract}

\section{INTRODUCTION}

Sperm-agglutinating antibodies in serum from men were first described by Wilson (1954). Since then, they have repeatedly been demonstrated to be correlated with infertility (see review by Rümke, 1969). A high serum titre of these antibodies may cause sterility whereas a low titre may be compatible with fertility (Rümke \& Hellinga, 1959; Fjällbrant, 1967, 1968; Rümke, 1972).

Donor spermatozoa have generally been used for demonstration of spermagglutinating antibodies (Rümke \& Hellinga, 1959; Fjällbrant, 1968). These antibodies seem to be directed against different parts of the sperm cell since they cause various types of sperm agglutination. Head-to-tail sperm agglutination has been found more frequently than head-to-head agglutination but tail-to-tail and tail-tip-to-tail-tip agglutination have also been described (Wilson, 1956; Rümke \& Hellinga, 1959; Rümke, 1964, 1965, 1972; Bandhauer, 1966; Sobbe, Haferkamp \& Doepfmer, 1966; Friberg, 1974a, b). The techniques adopted for light microscopy may not always be sufficient for the observation of all the agglutination types and it seems probable that for such studies, a scanning electron microscope (SEM) with its better resolving power would be more suitable. We have used an SEM to examine the agglutinates obtained when donor spermatozoa have been agglutinated in diluted sera containing head-to-head sperm-agglutinating antibodies.

\section{MATERIALS AND METHODS}

Sera from six men with different titres of head-to-head sperm-agglutinating antibodies varying from 1:64 to 1:512 have been used for the present study. 
The antibodies have been demonstrated by a microagglutination technique (Friberg, 1974a). Sera from five men of proven fertility and without spermagglutinating antibodies were used as controls. All sera were repeatedly examined before selection for this study. Evidence for the antibody nature of the sperm-agglutinating substances was obtained by various fractionation experiments with the sperm-agglutinating sera (Friberg, 1974b).

Sera from the men were diluted 1:4 with phosphate-buffered saline (PBS), $\mathrm{pH} 7 \cdot 4$, to a final volume of $1 \mathrm{ml}$ and were mixed with $0.2 \mathrm{ml}$ semen from one donor with excellent sperm characteristics (Friberg, 1974a). Before the spermatozoa were added to the diluted sera, the concentration of the spermatozoa was adjusted with PBS to $40 \times 10^{6} / \mathrm{ml}$. After incubation for $4 \mathrm{hr}$, the samples were fixed by the addition of $10 \mathrm{ml}$ of a $2.5 \%$ solution of glutaraldehyde (Fulka AG, Basel) in Sörensen's phosphate buffer, $\mathrm{pH} 7 \cdot 4$.

When the fixed agglutinated or non-agglutinated spermatozoa had sedimented, the supernatant glutaraldehyde was removed very gently by pipette and replaced in a stepwise manner with distilled water. The samples were then dehydrated in the same way with $50,70,90,95$ and $100 \%$ acetone. The changes of the solutions were performed very cautiously so that the agglutinated spermatozoa would not be dispersed. Three drops of acetone containing agglutinated or non-agglutinated spermatozoa were then transferred from the $100 \%$ acetone solution by means of disposable pipettes to small glass plates glued onto the specimen stubs of the microscope. The specimens obtained after the acetone had evaporated were coated with gold-palladium membranes and observed in a Jeol JSM-3 SEM. The microscope was operated at $25 \mathrm{kV}$ with $0.01 \mu \mathrm{A}$. Only the central areas of the glass plates were examined.

\section{RESULTS}

\section{Light microscopy}

The donor spermatozoa gave a distinct head-to-head agglutination in the sera from men with head-to-head sperm-agglutinating antibodies. The agglutinates consisted of about five to fifteen spermatozoa. No agglutination of the donor spermatozoa was observed in the control sera.

\section{Scanning electron microscopy}

Examination of the SEM glass plates with spermatozoa incubated in sera with head-to-head sperm-agglutinating antibodies revealed two types of sperm union. One type, which also was observed by light microscopy, concerned agglutination of different parts of the sperm heads (Pl. 1, Figs 1 and 2). The other type concerned agglutination of the first part of the head of one sperm cell to the post-nuclear cap region of the next sperm cell (PI. 1, Fig. 3). In these agglutinates, two to four spermatozoa participated. Only two of the six sera containing head-to-head sperm-agglutinating antibodies also showed this second agglutination type.

Incubation of donor spermatozoa in the non-agglutinating control sera resulted in a loose distribution of spermatozoa all over the central part of the glass plates. Aggregated spermatozoa were only occasionally observed. 

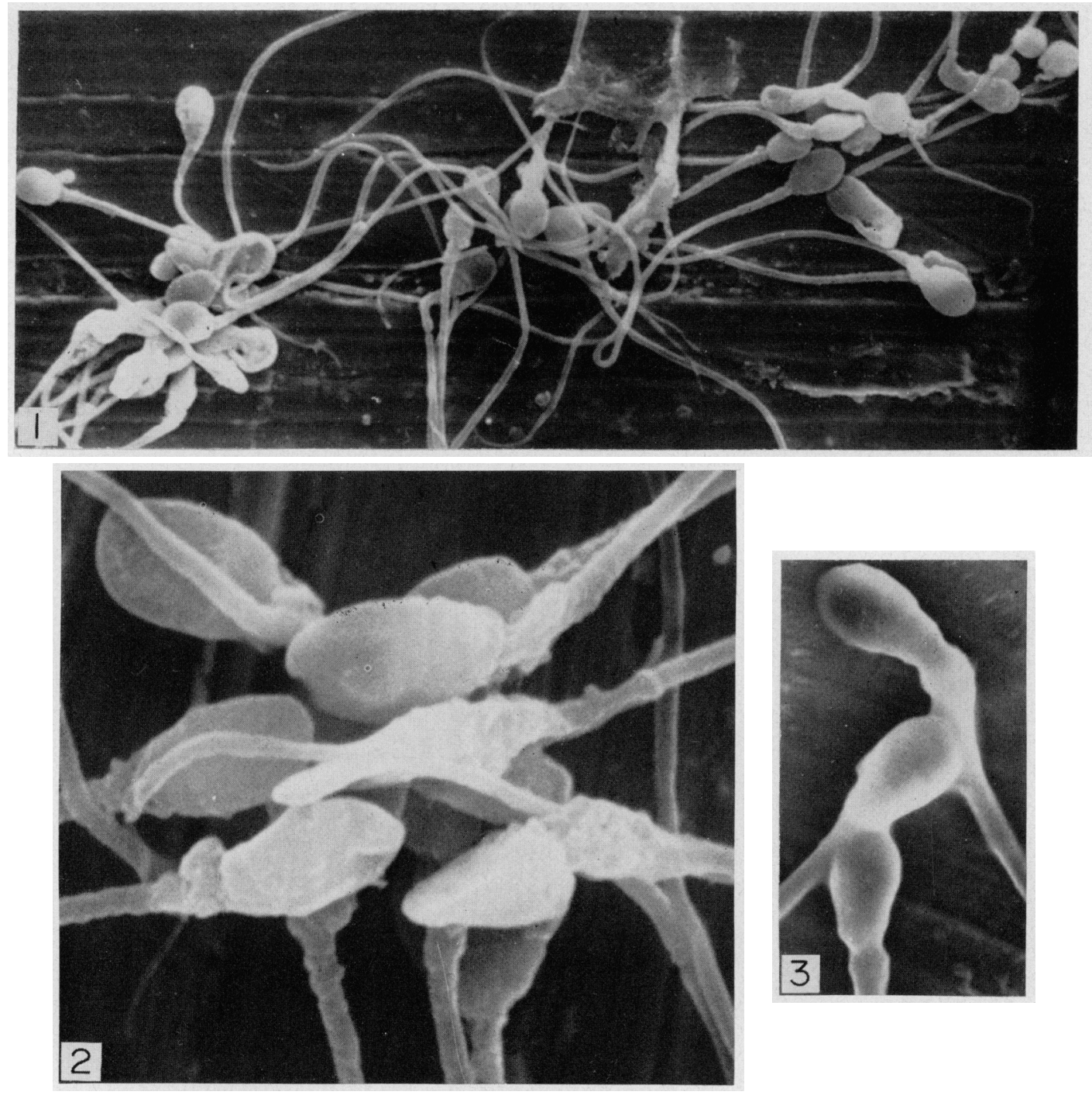

Fis. I. Human spermatoroa agglutinated head-to-head by eperm-agglutinating antibodies. Each agglutinate is composed of en we fiftern spermatozor. $\times 850$.

Fir. 2. Hunan spermatozoa agglutinated head-to-head. $\times 2700$.

lis: 3. Agglutinates of human spermatezon between the anterior part of the headef one spermalozoon and the pownuclear cap region of another sperm erll, $\times 1700$. 


\section{DISCUSSION}

Sperm-agglutinating antibodies in human sera may be detected by both macroscopic and microscopic techniques. The macroscopic sperm-agglutination technique described by Kibrick, Belding \& Merrill (1952) does not disclose the agglutination type of the spermatozoa. With microagglutination techniques (Rümke \& Hellinga, 1959; Franklin \& Dukes, 1964; Bandhauer, 1966; Friberg, 1974a), it has only been possible to distinguish between head-to-head, head-to-tail, tail-to-tail and tail-tip-to-tail-tip sperm agglutination. It is more difficult to find out whether different agglutination types are present within these 'main' agglutination types. The present experiments, however, have demonstrated that an SEM may be used for such studies.

It has been known for a long time that human spermatozoa carry different head and tail antigens (Henle, Henle \& Chambers, 1938). Immunofluorescent techniques (IFTs) may be used to refine the localization of the antigens, and Hjort \& Hansen (1971) have reviewed the literature. These authors also examined sera from women using an indirect IFT with washed methanolfixed human spermatozoa as antigen. Antibodies which reacted with antigens on the anterior part of the sperm head (the acrosome), the equatorial segment, the postnuclear cap region, and the tail were demonstrated. Later Hansen \& Hjort (1971) also described the presence of the same four antibodies in sera from infertile men. Antibodies against one or even two of these antigens were found in some sera.

Female sera containing antibodies against the four different antigens detected by means of an indirect IFT were not sperm-agglutinating when tested by the Kibrick macroscopic sperm-agglutination technique (Hjort \& Hansen, 1971). However, Feltkamp, Kruyff, Ladiges \& Rümke (1965), using the indirect IFT with unfixed human spermatozoa as antigen, found a correlation between staining and the presence of sperm-agglutinating antibodies in sera from infertile men, but no association between the staining pattern and the type of agglutination of the spermatozoa. Rümke (1968) observed immunofluorescent staining of the sperm head or mid-piece in ten out of eleven sera from men with high titres of sperm-agglutinating antibodies as measured by means of the Kibrick technique. The possibility of a correlation between the staining pattern with the indirect IFT using methanol-fixed human spermatozoa as antigen and the titre and type of sperm-agglutinating antibodies observed with the microagglutination technique will be the subject of a further study.

\section{AGKNOWLEDGMENTS}

This study was supported by the Ford Foundation, New York (Grant No. 66-405 to Professor Carl Gemzell) and by the Swedish Medical Research Council (Project No. 12X-70). The skilful technical assistance of Mr Bengt Wieselblad is gratefully acknowledged.

\section{REFERENGES}

BANDHAUER, K. (1966) Immunoreaktionen bei Fertilitätsstörungen des Mannes. Urol. int. 21, 247. 
Feltkamp, T. E. W., Kruyfr, K., Ladiges, N. C. J. J. \& Rümke, P. (1965) Autospermagglutinins: immunofluorescent studies. Ann. N.Y. Acad. Sci. 124, 702.

FJällbrant, B. (1967) Fertility in a man auto-immunized to spermatozoa. F. Reprod. Fert. 14, 143.

FJällbRant, B. (1968) Sperm agglutinins in sterile and fertile men. Acta obstet. gynaec. scand. 47, 89.

Franklin, R. R. \& Dukes, C. D. (1964) Antispermatozoal antibody and unexplained infertility. Am. $\mathcal{F}$. Obstet. Gynec. 89, 6.

FriberG, J. (1974a) A simple and sensitive micromethod for demonstration of sperm-agglutinating antibodies in serum from infertile men and women. Acta obstet. gynaec. scand., Suppl. 36, 21.

FriberG, J. (1974b) Immunological studies on sperm-agglutinating sera from men. Acta obstet. gynaec. scand., Suppl. 36, 43.

Henle, W., Henle, G. \& Chambers, L. A. (1938) Studies on the antigenic structure of some mammalian spermatozoa. F. exp. Med. 68, 335.

HANSEn, K. B. \& HJORT, T. (1971) Immunofluorescent studies on human spermatozoa. II. Characterization of spermatozoal antigens and their occurrence in spermatozoa from the male partners of infertile couples. Clin. exp. Immunol. 9, 21.

HJORT, T. \& HANSEN, K. B. (1971) Immunofluorescent studies on human spermatozoa. I. The detection of different spermatozoal antibodies and their occurrence in normal and infertile women. Clin. exp. Immunol. 8, 9.

Kibrigk, S., Belding, D. L. \& Merrill, B. (1952) Methods for the detection of antibodies against mammalian spermatozoa. II. A gelatin agglutination test. Fert. Steril. 3, 430.

RüMKE, P. (1964) Sperm-agglutinating auto-antibodies. Their relation to male infertility. Proc. $2 n d$ Int. Congr. Endocr., London, p. 906.

RümkE, P. (1965) Autospermagglutinins: a cause of infertility in men. Ann. N.Y. Acad. Sci. 124, 696.

RüMKE, P. (1968) Sperm-agglutinating auto-antibodies in relation to male infertility. Proc. R. Soc. Med. $61,275$.

RÜMKE, P. (1969) Clinical aspects of autoimmunity to spermatozoa in men. In Immunology and Reproduction, p. 251. Ed. R. G. Edwards. Int. plann. Parent. Fedn, London.

RüMKe, P. (1972) Autoimmunität gegen Spermatozoen und Unfruchtbarkeit des Mannes. Andrologie, 4, 191.

Rümke, P. \& Hellinga, G. (1959) Autoantibodies against spermatozoa in sterile men. Am. F. clin. Path. 32, 357.

Sobbe, A., Haferkamp, O. \& Doepfmer, R. (1966) Serologische und immunhistologische Untersuchungen an Sperma und Seren von Männern steriler Ehen. Dt. med. Wschr. 91, 1234.

Wirson, L. (1954) Sperm agglutinins in human semen and blood. Proc. Soc. exp. Biol. Med. 85, 652.

WrLson, L. (1956) Sperm agglutination due to auto-antibodies. Fert. Steril. 7, 262. 